\title{
Makna dan Klasifikasi Amanah Qur'ani Serta Relevansinya dengan Pengembangan Budaya Organisasi
}

\author{
Rahmad Hakim ${ }^{1}$, Adib Susilo ${ }^{2}$ \\ ${ }^{1}$ Universitas Muhammadiyah Malang, ${ }^{2}$ International Islamic University of Malaysia \\ 1rahmadhakim@umm.ac.id, 2adib.susilo27@gmail.com
}

DOI: $10.29240 /$ alquds.v4i1.1400

Submitted: 2019-02-26 | Revised: 2020-03-19| Accepted: 2020-04-13

\begin{abstract}
Amanah has a significant role in Islam. In some mandate authority, amanah is one of the conditions that must be fulfilled. This study aims to conduct an in-depth analysis related to the meaning of the mandate and its classification in relation to the development of organizational culture. This research is qualitative with documentation as the technique of collecting data. This technique is carried out by examining documents related to the interpretation of the mandate through several interpretive literatures and also other works. The conclusion of the study states that the meaning of amanab is obedience, security, and keeping promises. Furthermore, the classification of amanab in the context of developing organizational culture is as a criterion for faith, a criterion for choosing colleagues, as an organizational culture, and as one of the criteria for the success of a believer. Thus, the Qur'anic meaning and classification of amanah play a role in enriching the development of organizational culture in thedisruptive era.
\end{abstract}

Keywords: Amanah, Meaning and Classification, Organizational Culture Development.

\begin{abstract}
Abstrak. Amanah memiliki peran signifikan dalam agama Islam.Pada beberapa kewenangan amanah merupakan salah satu syarat yang harus di penuhi.Penelitian ini bertujuan untuk melakukan analisis mendalam terkait makna amanah dan klasifikasinya dalam kaitan pengembangan budaya organisasi.Penelitian ini adalah kualitatif dengan teknik pengumpulan data dokumentasi teknik ini dilkukan dengan telaah pada dokumen-dokumen yang terkait dengan tafsir tentang amanah melalui beberapa literatur tafsir dan juga karya lainnya.Kesimpulan penelitian menyatakan bahwa maknaamanah adalah ketaatan, rasa aman, dan menepati janji.Selanjutnya, klasifikasi amanah dalam konteks pengembangan budaya organisasi adalah sebagai kriteria keimanan, kriteria meimilih rekan kerja, sebagai budaya organisasi, dan sebagai salah satu kriteria kesuksesan seorang mukmin.Dengan demikian, makna dan klasifikasi amanah Qur'ani dapat memiliki peran dalam memperkaya pengembangan budaya organisasi di era disrupsi.
\end{abstract}

Kata Kunci: Amanah, Makna dan Klasifikasi, Pengembangan Budaya Organisasi. 


\section{Pendahuluan}

Amanah merupakan salah satu konsep kunci dalam Islam. Sebab amanah merupakan tolak ukur dari keimanan seseorang. Amanah sebanding dengan keimanan seseorang secara umum. Dengan demikian, jika ingin melihat keimanan seseorang, dapat dilihat dengan amanah seseorang terhadap Allah, orang lain dan dirinya sendiri. Dalam al-Qur'an (QS. al-Mā'idah [5]: 8), dinyatakan bahwa keadilan mendekati ketakwaan. Sementara pada surah yang lain, (QS. An-Nisā' [4]: 58) dinyatakan bahwa amanah dan adil berdiri sejajar. Bahkan para mufassir seperti Abi Hayyan al-Andalusi menyatakan bahwa tahapan dalam berlaku amanah dan adil ialah, memulai dengan diri sendiri yang menjaga amanah, kemudian menyerukan kepada orang lain, setelah itu barulah menetapkan keputusan atau suatu perkara dengan adil. Meskipun langkahlangkah ini tidak selama berjalan secara periodik, dapat pula berjalan secara komprehensif bersama-sama.

Penelitian tentang amanah telah dilakukan oleh beberapa peneliti, diantaranya Supriyanto tentang manajemen amanah di perbankan. Secara umum amanah dimaknai sebagai penerimaan tanggung jawab sebagai seorang manusia dalam mengelola sesuatu dengan berdasarkan pada kesadaran diri bahwa segala yang ia lakukan memiliki konsekuensi terhadap kehendak Tuhan. Lebih lanjut penerapan amanah dapat dilakukan melalui tiga tahap, pertama individual operation initiative, kedua team amanah dan total quality amanah management, dan terakhir yaitu dengan high integration dan involved workforce. ${ }^{1}$ Di sisi lain, Hakim menyatakan bahwa amanah dapat dijadikan sebagai nilai budaya organisasi pada organisasi pengelola zakat (OPZ). ${ }^{2}$

Sementara itu, ditinjau dari segi penafsiran ayat-ayat al-Qur'an amanah berkaitan erat dengan hubungan antara manusia dengan Allah, hubungan manusia dengan manusia serta komitmen terhadap diri sendiri yang artinya selalu terkait dengan kegiatan muamalah manusia. Setidaknya terdapat empat poin penting dalam menjaga amanah, yaitu: menjaga hak Allah, menjaga hak manusia, menjauhkan dari sikap acuh dan berlebihan, terakhir tanggung jawab. ${ }^{3}$ Di sisi lain, berdasarkan tinjauan hadits, amanah merupakan kewajiban manusia terhadap Allah, sebab manusia tercipta di muka bumi sebagai khilafah. Amanah bukan hanya perkara akad antara dua pihak yang bersepakat namun juga komitmen untuk memberikan rasa aman kepada pihak-pihak terkait. Maka dari

${ }^{1}$ Eko S., (2000). "Konsep Manajemen Amanah (Kajian Teoritik Terhadap Sistem Fillacial Perbankan Islam)," EL HARAKAH Jumal Budaya Islam 2(1), 46-50.

${ }^{2}$ Hakim, R., Sawarjuwono, T., \& Djalaluddin, A. (2018). Proposing the value of Amanah as the foundation of Zakah organizational culture. Opcion, 1(2), 35-21.

${ }^{3}$ Zainal A. \& Fiddian K., (2017). "Penafsiran Ayat-Ayat Amanah Dalam Al-Qur'an," Jurnal Syahadah, 5(2), 119-44. 
itu, kriteria amanah dapat dilihat dari dua hal penting, yaitu: keimanan atau religiusitas serta sikap professional dalam menjalankan tugas. ${ }^{4}$ Dengan demikian, karakter manusia kategori amanah terbagi menjadi beberapa bagian, yaitu: dapat dipercaya, bertanggung jawab, jujur, dan mampu melaksanakan tugas. ${ }^{5}$

Sementara itu, sikap atau karakter amanah memiliki hubungan dengan tingkat kesejahteraan seseorang. Kesejahteraan yang diukur adalah kesejahteraan subjektif dari mahasiswa perantau seperti satisfaction with live scale dan Positive and negative affect schedule. Untuk mengukur bagaimana amanah dapat berpengaruh terhadap kesejahteraan subjektif mahasiswa perantau maka skala amanah yang dibuat adalah hubungan antara manusia dengan Allah, manusia dengan manusia dan manusia dengan tuhan. Hasil penelitian menunjukkan bahwa amanah berpengaruh terhadap kesejahteraan subjektif secara efektif sebesar 12,6\%. Selain itu, terdapat korelasi positif dan signifikan antara amanah dengan kesejahteraan subjektif mahasiswa perantau. Sehingga tingkat amanah seseorang berpengaruh terhadap peningkatn kesejahteraan subjektif seseorang. ${ }^{6}$

Di sisi lain, amanah dapat menjadi bingkai dalam pengelolaan organisasi yang tidak hanya mengacu kepada Good Corporate Governance (GCG). Sehingga tidak hanya mengandalkan prinsip kewajaran, transparansi, akuntabilitas, dan responsibilitas. Akan tetapi keempat hal tersebut harus dibingkai dengan konsep amanah sehingga segala kegiatan tidak melulu berorientasi kepada profit akan tetapi kepada tujuan yang lebih muliah yaitu pertanggung jawaban kepada Allah. ${ }^{7}$

Sementara itu, budaya organisasi dalam berbagai literatur mampu mendorong kinerja suatu organisasi. ${ }^{8}$ Budaya organisasi dalam sebuah institusi merupakan hal yang mampu menciptakan nilai-nilai yang kemudian terkejawantahkan dalam kinerja. ${ }^{9}$ Hingga berdampak terhadap pelayanan yang dirasakan oleh stakeholder seperti konsumen dari perusahaan barang atau jasa, 1(1), 7-16.

${ }^{4}$ Reza P. D., (2016). “Amanah Dalam Perspektif Hadist,” Diroyab: Jurnal Ilmu Hadis,

${ }^{5}$ Ivan M. A. \& Desma H., (2016). "Pengukuran Konsep Amanah Dalam Pendekatan Kualitatif Dan Kuantitatif,” Jurnal Psikologi, 43(3), 194-206.

${ }^{6}$ Muflihah A. I. H., dkk., (2018). "Hubungan Antara Amanah Dan Dukungan Sosial Dengan Kesejahteraan Subjektif Mahasiswa Perantau," Psikobumaniora: Jurnal Penelitian Psikologi, 3(1) 101-116.

${ }^{7}$ Diska A. H. \& Gina H., (2013). "Membingkai Good Corporate Governance Amal Usaha Muhammadiyah Dalam Kerangka Amanah," Jurnal Akuntansi \& Investasi, 14(2), 85-95.

${ }^{8}$ Laksmi K., (2010). "Budaya Organisasi Dalam Meningkatkan Kinerja Karyawan," BISMA Jurnal Bisnis Dan Manajemen, 2(2), 159-66.

${ }^{9}$ Bambang H. \& Rusdin, (2013). "Budaya Organisasi, Penciptaan Nilai, Dan Kinerja Organisasi," Jurnal Administrasi Bisnis, 9(2), 82-94. 
yang pada gilirannya dapat meningkatkan kepuasan dan berujung kepada meningkatnya profit. ${ }^{10}$

Meskipun berbagai penelitian menunjukan bahwa budaya organisasi mampu meningkatkan kinerja dan produktivitas dalam sebuah organisasi namun ada perbedaan konsep dalam kepercayaan dan amanah walaupun terdapat persamaan antara amanah dan trust (keperacayaan). ${ }^{11}$ Namun pada konsep dasarnya kepercayaan merupakan salah satu indikator dari amanah. ${ }^{12}$ Lebih dari pada itu, amanah merupakan komitment terhadap diri sendiri, atas kepercayaan yang telah diberikan dari orang lain yang berhubungan langsung dengan Allah sebagaimana disebutkan dalam hadits qudsi bahwa Allah merupakan pihak ketiga dari orang yang bersyarikat. ${ }^{13}$

Oleh karena itu, diperlukan adanya konsepsi akan makna dan klasifikasi amanah dalam kaitannya pengembangan budaya organisasi. Sebab amanah dalam sebuah organisasi bukan hanya terbatas pada pemenuhan target kinerja, menjaga hubungan baik antara sesama manusia, tetapi memper erat hubungan manusia dengan sang pencipta. Hal ini juga berkaitan dengan tantangan yang dihadapi dewasa ini. ${ }^{14}$ Sehingga kegiatan dalam organisasi ataupun perusahaan tidak hanya berbicara tentang profit, tetapi berbicara pula tentang nilai-nilai kehidupan. ${ }^{15}$ Dengan demikian, penelitian ini bertujuan untuk membahas tentang makna dan klasifikasi amanah Qur'ani dalam kaitannya dengan pengembangan budaya organisasi. Guna mencapai tujuan penelitian, dilakukan elaborasi pendapat para mufassir melalui karya-karyanya tentang makna amanah dan klasifikasinya. Selanjutnya adalah dengan melakukan analisis mendalam pada literatur yang membahas tentang budaya organisasi dalam perspektif Islam. Hasil dari kedua langkah tersebut adalah untuk mencapai kesimpulan makna dan klasifikasi amanah Qur'ani dalam kaitannya dengan pengembangan budaya organisasi.

10 Masdar, S., Asmorowati, S., \& Irianto, J. (2009). Manajemen Sumber Daya Manusia Berbasis Kompetensi Untuk Pelayanan Publik. Surabaya: Airlangga University Press. , 23

${ }_{11}$ Majeed, Y., Khalid, Z., \& Khan, M. A. (2011). The impact of Islamic leadership on organizational Objectives. Far East Journal of Marketing and Management, 1(5), 54-65.

12 Ivan M. A. \& Desma H., (2016). "Pengukuran Konsep Amanah Dalam Pendekatan Kualitatif Dan Kuantitatif," Jurnal Psikologi, 43(3), 194-206. 1(1), 7-16.

${ }^{13}$ Reza P. D., (2016). “Amanah Dalam Perspektif Hadist,” Diroyah: Jurnal Ilmu Hadis,

14 Salleh, M. J., \& Mohamad, N. (2012). Islamic principles of administration: implications on practices in organization. In Technology, Science, Social Sciences and Humanities International Conference, Langkawi, 14 \& 15 November 2012, Malaysia. (1), 1-12

${ }^{15}$ Ivan M. A. \& Jhon H., (2018). "Pedagang Yang Amanah: Studi Eksplorasi Dengan Pendekatan Psikologi Indigenous,” PSYMPATHIC : Jurnal Ilmiah Psikologi, 4(1), 33-40. 


\section{Pembahasan}

\section{Definisi Amanah}

Amanah berasal dari kata arab 'amuna-ya'munu-amānatan' berarti kondisi tenang dan tentram, karena terbebas dari bahaya dan bencana, atau tiada keraguan dan ketakutan akan terjadinya sesuatu yang buruk. Amanah juga berasal dari kata 'amana-yamunu-amanatan' berarti titipan (wadi’ab) yang terdiri dari unsur kepercayaan (nazāhah), kejujuran (sidiq), ikhlas, janji atau kewajiban (wafä'), konsisten dan komitmen (tsabāt 'alal 'Abdi). ${ }^{16}$

Menurut Mandzur amanah juga memiliki arti; (1) ketaatan, (2) ibadah, (3) titipan (wadìab), (4) kepercayaan (tsiqah), (5) dan keamanan. Di sisi lain, amānah merupakan bagian daripada iman, sebagaimana Rasulullah Saw. bersabda, "alImanu Amānah, wa là dìna liman là amānata lahu"(HR. Bukhari dan Muslim)-Iman merupakan bentuk dari sebuah amanah, dan tiada Agama (iman), bagi siapa saja yang tidak menjaga amanah yang diberikan kepadanya. ${ }^{17}$ Lawan kata (antonim) dari amanah adalah khianat (ingkar).

Amanah dapat juga dimaknai sebagai niat yang menjadi keyakinan seseorang, direfleksikan dengan lisan dan melaksanakan apa yang diwajibkan secara kongkrit dengan demikian Allah memberikan kedamaian kepadanya. ${ }^{18}$

Selain itu, amanah juga memiliki arti ketenangan dan ketentraman. Sebagaimana Rasulullah Saw. bersabda, "wa Taqa'u al-amanatu fil ardhi". Maksud amānah dalam hadist ini adalah bahwa wilayah tersebut berada dalam kondisi aman karena tiada seorang pun yang khawatir akan adanya ancaman (hewan buas). Di sisi lain, amanah berarti juga sebagai kondisi dimana seseorang dapat menjelaskan dengan cermat (transparan dan akuntabel) terhadap sebuah isu yang menjadi perdebatan di masyarakat, sehingga dapat mencegah adanya kekacauan dan perpecahan (kondisi menjadi tidak aman). ${ }^{19}$

Menurut Asfahani amanah merupakan ketenangan jiwa dan perasaan dengan ketiadaan rasa takut. Disisi lain, juga diartikan sebagai istilah dari ketidakpercayaan manusia terhadap sesuatu (sesorang) karena adanya unsur kebohongan misalnya: tidak berkata jujur dan menyembunyikan sesuatu. ${ }^{20}$

${ }^{16}$ Lewis Ma’lūf, al-Munjid fi al-Lughah, Cet. I, (Lebanon-Beirūt: Dār al-Masyriq, 2000),

${ }^{17}$ Ibn Mandzur, Lisan al-'Arab, Juz.I, (Qahirah: Darul Ma’arif, 1998), , 140

${ }^{18} \mathrm{Ibid}$, Ibn Mandzur, Lisan al-'Arab..., , 142

${ }^{19}$ Ibid, Ibn Mandzur, Lisan al-'Arab,.., 140

20 Rāghib al-Asfāhanī, al-Mufradāt fi Gharīb al-Qur'ān, tahqīq. Muhammad Sayyid Kailānīy, (Beirūt-Lebanon: Dār al-Ma'rifah, t.t), , 25-26 
Selanjutnya menurut Atsīr, seseorang dikatakan amanah jika memiliki keriteria sebagai berikut: ${ }^{21}$ a) orang yang mempunyai kemampuan dan keahlian khusus dalam mengelola suatu urusan, sehingga membuat kondisi menjadi tentram dan tenang. Perilaku, perkataan dan ucapanya menenangkan orang lain, b) orang yang dipercaya perkataanya karena tidak pernah berbohong, c) orang yang membuat orang lain merasa tenang, tentram dan dipercaya, sehingga tidak takut ditipu dan dibohongi.

Secara istilah menurut Ibnu 'Abbas, amanah meliputi ketaatan yang akan dibebankan kepada bumi, langit dan gunung sebelum dibebankan kepada Nabi Adam, namun bumi dan lainnya tidak mampu merimanya. Kemudian dikatakan kepada Nabi Adam: "Sesunggubnya aku telah memberikan amanab kepada langit, bumi dan gunung akan tetapi mereka menolak, apakah kamu mau mengambilnya?" Nabi Adam Berkata: "ya Allah, apakah bagian di dalamnya?" Allah berkata: "apabila kamu melakukannya dengan baik maka akan diberikan pahala, dan apabila buruk maka akan dikenakan siksa". Maka Nabi Adam mengambilnya. ${ }^{22}$

Menurut 'Ali bin Abi Talhah, dari Ibnu 'Abbas, amanah adalah segala kewajiban yang dibebankan kepada langit bumi dan gunung namun tidak mampu untuk mengambilnya. Kemudian diberikan kepada Nabi Adam dan diterimanya sebagaimana disebutkan dalam al-Qur'an: 'wa hamalaha al-insan innabu kana drulman jahulan' (QS. al-Ahzab[33]: 72).

Diriwayatkan oleh Dhihak, dari Ibnu 'Abbas, Mujahid, Sa'id bin Jubair, Hasan al-Basri, dan lainnya menyatakan bahwa amanah adalah segala kewajiban manusia. Pendapat lain, menyatakan bahwa amanah adalah taat. Menurut alA'masyi dari Abi Ad-Dhuha dari Masruq, berkata Abi bin Ka'ab, merupakan bagian dari amanah ialah wanita yang menjaga kemaluannya. ${ }^{23}$ Menurut Qatadah, amanah ialah agama, kewajiban-kewajiban (fara'id) dan batasan-batasan (budud). Abu Darda' memaknainya sebagai bersuci dari kotoran (janabab). Sedangkan Imam Malik menyatakan bahwa amanah ada tiga bagian, meliputi: shalat, puasa, dan bersuci dari kotoran.

Ibnu 'Arabi mendefiniskan amanah sebagai segala sesuatu yang diambil atas izin pemiliknya untuk dimanfaatkan. ${ }^{24}$ Menurut Az-Zamakhsyari, makna khianat adalah kurang, sebagaimana memenuhinya (amanah) adalah berarti

${ }^{21}$ Lisan al-'Arab, Juz.I, (Qahirah: Darul Ma’arif, 1998), , 140

${ }^{22}$ Imāduddīn Abī al-Fidā’ (Ibnu Katsīr), Tafsì al-Qur'ān al-'Adžim, Juz. XI, Tahqīq. Musthafā as-Sayyid Muhammad, et. al. (Qāhirah: Mu’assasah Qurtūbah, 1421 H-2001 M), , 250252

${ }^{23}$ Ibid, Imāduddīn Abī al-Fidā’ (Ibnu Katsīr),. , 250-252. Lihat juga: Abi Hayyan alAndalusi, Tafsir al-Babrul Mubith, Juz.VII, Cet. I, (Beirut-Lebanon: Darul Kutub al-'Alamiyyah, 1993), , 243

${ }^{24}$ Ibnu 'Arabi, Ahkam al-Qur'an, Juz. 1, Tahqiq. Muhammad 'Abdul Qadir 'Atha', (Beirut-Lebanon: Darul Kutub al-'Alamiyyah, 2003), , 570 
penuh atau lengkap. Dengan demikian, amanah di artikan sebagai iman yang penuh, sedangkan mengkhianatinya berarti iman menjadi kurang. Sebab jika seseorang mengkhiati seseorang mengenai suatu hal, maka seseorang tersebut memiliki kekurangan didalamnya. ${ }^{25}$ Disisi lain, al-Andalusi dan az-Zuhaili, dan ini merupakan pendapat mayoritas (jumbur) mufassir, bahwa amanah (plural: amanat) merupakan segala sesuatu yang dipercayakan Allah Swt kepada hambanya. Baik dalam bentuk perkataan, perbuatan dan kepercayaan. Termasuk dalam kategori ini, adalah segala kewajiban dari hal-hal yang harus dilakukan dan ditinggalkan sebagaimana dipercayakan kepada manusia-manusia (kaum-kaum) sebelumnya, dan secara khusus amanat kemanusiaan (antara manusia dengan manusia; bidang muamalat). ${ }^{26}$

Definisi lain menyatakan bahwa amanah ialah tugas, ketaatan, dan kebebasan, dan kebebasan dalam memilih (ikbtiyar) dan kebebasan dalam berbuat atas langit, bumi dan gunung. Makhluk-makhluk selain manusia juga diminta untuk menjalankan dan menjaga amanah tersebut, maka makhlukmakhluk tersebut menolak karena takut lalai dan mengingkarinya. Namun manusia menyanggupinya (untuk menunaikan amanah) melalui Nabi Adam ayah seluruh Manusia (abu al-basyar) dengan segala kelemahannya, begitu pula jin, sesungguhnya sebagian besar dari mereka cenderung berlaku dzalim terhadap diri sendiri, dan bodoh terhadap apa yang dibebankan kepadanya. ${ }^{27}$ Menurut AsSuyuthi dan al-Mahalli serta at-Thabari, amānah merupakan kewajiban yang harus dipenuhi oleh pemerintah atau suatu badan yang mengurusi urusan ummat Muslim kepada ahlinya (seseorang yang berbak atas sesuatu). ${ }^{28}$

Secara umum amanah kepada manusia meliputi beberapa prinsip sebagai berikut: $^{29}$ a) Jika barang titipan, maka diharuskan untuk memberikan kepada yang berhak sebelum diminta, b) Jika barang temuan, maka dilakukan pengumuman selama setahun dengan harapan dapat ditemukan pemiliknya. Jika tidak ditemukan maka langkah selanjutnya barang tersebut dimakan, jika barang temuan berbentuk konsumtif, c) Jika barang gadai, maka tidak diperkenankan

\footnotetext{
${ }^{25}$ Imam az-Zamakhsyari, Tafsir al-Kasysyaf, Juz.2, Cet. I, (Riyadh: Maktabah 'Abikan, 1998), , 572-573

26 Abi Hayyan al-Andalusi, Tafsir al-Bahrul Mubith, Juz.VI, Cet. I, (Beirut-Lebanon: Darul Kutub al-'Alamiyyah, 1993), , 367-368. Lihat juga: Wahbah az-Zuhaily, Tafsir al-wajiz 'ala Hamisy al-Qur'an, Cet.II, (Damaskus-Suriah: Darul Fikr, 1996), , 88. Lihat juga: 'Imaduddin Abi al-Fida', Tafsir al-Qur'an al-'Adzim, , 58

${ }^{27}$ Wahbah az-Zuhaily, Tafsir al-wajiz 'ala Hamisy al-Qur'an, Cet.II, (Damaskus-Suriah: Darul Fikr, 1996), , 428

${ }_{28}$ Abī Ja'fār at -Thabarī, Tafsìr at-Thabarì, Juz. VII,Cet. I, Tahqīq. 'Abdullāh Ibn 'Abdullah al-Muhsin at-Turkìy, (t.t: Hijr li at-Tab’ah wa An-Nasyr, 2003 M-1423 H), , 170.

${ }^{29}$ Ibid, Ibnu 'Arabi, Abkam al-Qur'an, , 571
} 
untuk dikembalikan barang tersebut sampai ia menebusnya, d) jika barang sewa, maka diharuskan untuk mengembalikannya kepada si pemilik sebelum diminta telah selesai kepetingannya.

\section{Klasifikasi Amanah}

al-Andalusi menyatakan bahwa amānah meliputi dua hal; pertama, amānah kepada Allah yaitu suatu amānah dimana bumi dan gunung tidak mau menerimanya, akan tetapi manusia mau menerimanya. yaitu tauhīd dalam hal ini adalah beribadah kepada Allah Swt. Kedua, amanah dengan berbuat baik kepada sesama manusia dalam beberapa hal berikut; (1) pembagian harta. (2) adil dalam hukum. (3) amānah dalam titipan. (4) amanah dalam bersaksi. (5) amanah dalam pinjaman. ${ }^{30}$ Selanjutnya tertib yang benar dalam menjalankan amānah adalah dengan memulai dari diri sendiri untuk senantiasa mengambil manfaat dan menjauhi segala kerusakan dan bahaya (ibädah kepada Allah Swt). Kemudian dengan melakukan perbuatan baik kepada orang lain dengan menjalankan perbuatan baik meliputi menyampaikan amanah kepada ahlinya, dan terakhir menetapkan atau memutuskan sesuatu dengan kebenaran (adil).

Menurut Ibnu Katsīr, amānah secara umum merupakan hal-hal yang diwajibkan kepada manusia, dari hak-hak Allah Swt. atas hambanya seperti shalat, zakat, puasa kafärat (denda), nadzar. Selain itu, terdapat hak-hak seorang hamba terhadap sesamanya, seperti; titipan dan juga akad-akad yang memiliki unsur saling percaya antara keduanya, maka Allah memerintahkan agar kewajiban tersebut ditunaikan. ${ }^{31}$

Fakhruddīn ar-Rāzi menyatakan bahwa ummat Mu'min diperintahkan untuk melaksanakan amanah di dalam segala urusan, baik dalam urusan madzhab dan keagamaan, maupun urusan dunia dan mu'ämalah (hubungan dengan manusia). ${ }^{32}$ Dalam konteks amanah, manusia memiliki tiga hubungan erat antara manusia dengan tuhannya. Menusia sesama manusia, dan dengan dirinya sendiri. Maka pelaksanaan amanah harus dilakukan kepada semua. ${ }^{33}$

Pelaksanaan amanah kepada Tuhannya ditandai dengan pelaksanaan segala perintah seperti shalat, zakat, puasa, wudhu', dan menjaga kemaluan. Selain itu juga berbentuk; (1) amanah lisan adalah dengan tidak berbohong,

${ }^{30}$ Abī Hayyān al-Andalūsī, Tafsri al-Bahr al-Mubith, Juz. III, tahqīq. Syaikh 'Ādil Ahmad 'Abd al-Marjūd \& Syaikh 'Ali Mahmūd Ma'rad, (Beirūt-Libanon: Dār al-Kutub al-'Ālamiyyah, 1413 H-1993 M), , 289

31 'Imāduddīn Abī al-Fidā' (Ibnu Katsīr), Tafsìr al-Qur'ān al-'Adžìm, Juz. IV, Tahqīq. Musthafā as-Sayyid Muhammad, et. al. (Qāhirah: Mu’assasah Qurtūbah, 1421 H-2001 M), , 124 125

${ }^{32}$ Muhammad Fakhruddīn Ar-Rāzi, Tafsìr al-Kabìr wa Mafātihu al-Ghayb, Juz. X, Cet.I, (Beirūt-Libanon: Dār Al-Fikr, 1401 H - 1981 M), , 142-143

${ }^{33}$ Muhammad Fakhruddīn Ar-Rāzi, Tafsì al-Kabì wa Mafätihu al-Ghayb, , 143 
ghībah, adu domba, kufur (ingkar), bid'ah, berbuat kerusakan (fahsy dan mungkar), dan lain sebagainya. (2) amanah mata adalah dengan tidak melihat sesuatu yang haram, dan (3) amanah telinga (pendengaran) adalah dengan tidak mendengar sesuatu yang dilarang dan melalaikan, dan mendengarkan kerusakan dan kebohongan.

Selanjutnya, pelaksanaan amanah kepada sesama manusia, meliputi; (1) pengembalian atau penyampaian titipan kepada ahlinya, (2) menghindari untuk mengurangi timbangan dan ukuran dalam segala transaksi (jual beli), (3) tidak mengumbar aib orang lain, (4) keadilan pemerintah (yang memiliki kekuasaan) atas rakyatnya, dan (5) keadilan ulamă atas orang awam (rakyat jelata) agar tidak membawa mereka kepada fanatik (ta'assub) yang berlebiahan atau bathil, akan tetapi membimbing mereka kapada keyakinan dan perbuatan yang bermanfaat bagi mereka untuk agama dan akhiratnya. (6) tidak mudah mengkafirkan, (7) amanah istri kepada suaminya untuk menjaga kemaluannya.

Sementara itu, pelaksanaan amanah kepada diri sendiri diantaranya dengan melakukan ikhtiyär agar senantiasa memilih sesuatu yang paling bermanfaat dan paling baik akibatnya bagi agama dan dunianya, dan tidak mendahulukan syahwat dan marah dalam memutuskan sesuatu, sehingga membahayakan kehidupan akhiratnya.

Di sisi lain, Sayyid Quthb menyatakan bahwa menunaikan amanah merupakan bagian dari akbläq ummat Muslim yang harus dilaksanakan. Dimulai dengan amanah yang terbesar yaitu amānah kepada Allah Swt. Suatu amānah yang bumi dan langit serta gunung-gunung tidak mau memikulnya dan takut memikulnya, akan tetapi hanya manusia yang mau memikulnya. Amānah ini adalah amanah bidāyah, ma'rifah dan iman kepada Allah dengan niat, kehendak hati, kesungguhan dan arahan. Inilah amanah fitrah insaniyah (fitrah manusia) yang khusus. Selain manusia, makhluk lainnya (hewan dan tumbuhan) diberi ilhäm oleh Allah untuk mengimani-Nya, mengikuti petunjuk-petunjuk-Nya, mengenal-Nya, beribadah kepada-Nya, dan menaati-Nya. Juga ditetapkan-Nya untuk mengikuti undang-undang alamnya tanpa melakukan upaya, tanpa kesengajaan, tanpa kehendak, dan tanpa arahan. Maka, hanya manusia sendirilah yang diserahkan kepada fitrah, akal, ma'rifah, irädah, tujuan, dan usahanya untuk sampai kepada Allah. Inilah amānah yang dipikul oleh manusia dan yang pertama harus ditunaikan. ${ }^{34}$

Dari amanah terbesar ini muncul amanat-amanat lain yang diperintahkan Allah untuk ditunaikan. Amanah tersebut antara lain; pertama, amanah persaksian

${ }^{34}$ Sayyid Quthb, Tafsì fi Zhiläli Al-Qur'ān, Juz. II, Cet. I. alih bahasa: As'ad Yasin, dkk., (Jakarta: Gema Insani Press: 2001), , 396-397 
(syahadah) terhadap agama Islam didalam jiwa yang dapat menimbulkan pengaruh terhadap orang lain. Maka tidaklah cukup seorang memberikan persaksian bagi iman pada dirinya sendiri saja, apabila ia tidak menyeru orang lain kepada-Nya. Ia juga belum di anggap telah menunaikan amanah dakwah, tabligh dan memberikan keterangan (bayan) yang merupakan salah satu unsur dari sekian banyak amanah.

Kedua, memberikan persaksian bagi agama Islam dengan berusaha meneguhkannya di muka bumi sebagai manhäj (metode) bagi kaum muslimin dan seluruh manusia, dengan segenap daya dan sarana yang dimilikinya, baik pribadi maupun masyarakat. Maka menegakkan manhaj ini dalam kehidupan manusia merupakan amanah yang terbesar setelah beriman itu sendiri. Tidak ada seorang atau golongan manusia pun yang diperkenankan untuk lepas dari amanah ini. Oleh karena itu "jibad terus berlaku bingga hari kiamat".

Amanah lain dalam kategori ini adalah amanah dalam hubungan sesama manusia (mu'amalah) dan menunaikan amanah kepada mereka. Amanah ini berupa titipan materi, amanah yang berupa kesetiaan rakyat kepada pemimpin dan kesetiaan pemimpin kepada rakyat, amanah untuk memelihara anak, amanah untuk menjaga kehormatan jamaah, harta benda dan wilayahnya, serta semua kewajiban dan tugas keduniaan secara garis besar.

Selaras dengan Quthb, Hamka menyatakan bahwa amanah terbagi menjadi dua: pertama, amanah raya yang merupakan tugas yang dipikulkan Allah Swt atas pri-kemanusiaan seluruhnya, menjadi khalifatullah fil Ardhi. Amanah ini tidak terpikul oleh langit dan bumi, bukit maupun gunung. Hanya hati seorang Mu'min yang sanggup memikul amanah ini, sebab hati mereka lebih luas daripada langit dan bumi serta lebih tinggi daripada bukit dan gunung.

Kedua, adalah amanah pribadi yang merupakan tugas kita masing-masing individu menurut kesanggupan diri, bakat dan nasib. Sebagaimana Allah berfirman bahwa tugas hidup hanyalah pembahagian pekerjaan bukanlah kemuliaan dan kehinaan. Sebab mereka yang mulia disisi Allah ialah yang peling bertaqwa kepada-Nya. ${ }^{35}$

\section{Definisi Budaya Organisasi}

Menurut Cherrington ${ }^{36}$ Schein $^{37}$ Robbins $^{38}$, Rollinson, ${ }^{39}$ dan Newstroom \& Davis ${ }^{40}$ budaya organisasi mengacu ke suatu sistem makna bersama yang

35 Abdul Malik Karim Amrullah (HAMKA), Tafsìr Al-Az̧hār, Juz. XVIII,Cet. I, (Surabaya: H. Abdul Karim, 1976), , 16

${ }^{36}$ Cherrington, D. J. (1989). The Management of Individual and Organizational Performance: Instructor's Manual for Organizational Behavior. Allyn and Bacon. , 498

${ }^{37}$ Schein, Edgar H. "How can organizations learn faster?: the problem of entering the Green Room." (1992). , 16. $\quad$ Retrieved from https://dspace.mit.edu/bitstream/handle/1721.1/2399/SWP-3409-45882883.pdf 
dianut oleh anggota-anggotanya untuk membedakan organisasi itu terhadap organisasi lain. Lebih lanjut Huczynski \& Buchman ${ }^{41}$ menyatakan bahwa budaya organisasi adalah kumpulan nilai-nilai, kepercayaan, adat istiadat, tradisi, dan praktik yang relatif seragam dan bertahan lama yang dibagikan oleh anggota organisasi, dipelajari oleh karyawan baru, dan ditransmisikan dari satu generasi karyawan generasi berikutnya.

Sementara Kreitner \& Kinicki $^{42}$ mendefinisikan budaya organisasi sebagai suatu wujud anggapan yang dimiliki, diterima secara implisit oleh golongan dan menentukan bagaimana yang dirasakan, difikirkan oleh golongan tersebut, dan reaksi yang timbul terhadap lingkungan yag beragam. senada dengan Schein.

Hodge menyatakan bahwa budaya organisasi merupakan rekonstruksi dari dua tingkat karakteristik organisasi, yaitu; karakteristik yang nampak (observable), dan karakteristik yang tidak nampak (unobservable). Pada level yang nampak, karaktersitik ini berbentuk arsitektur, seragam, pola perilaku, peraturan, legenda, mitos, bahasan dan seremoni yang dilakukan oleh organisasi. Sedangkan pada level yang tidak nampak, berbentuk nilai-nilai yang diwariskan (shared values), norma-norma, sistem kepercayaan, asumsi-asumsi para anggota organisasi untuk mengelola masalah dan keadaan yang ada disekitarnya. ${ }^{43}$

Selanjutnya, Hofstede menyatakan bahwa terdapat 5 (lima) dimensi budaya yaitu: (1) Individualisme. (2) Kolektivisme. (3) Jarak kekuasaan. (4) Penghindaran ketidakpastian. (5) Maskulinitas. Sementara Schein (1992: 16), menjelaskan unsur-unsur budaya, yaitu: ilmu pengetahuan, kepercayaan, seni, moral, hukum, adat-istiadat, perilaku atau kebiasaan (norma) masyarakat, asumsi dasar, sistem nilai, pembelajaran, dan masalah adaptasi eksternal dan integrasi internal. $^{44}$

Jersey. , 248.

38 Robbins, SP (1998). Organizational Behavior, Prentice-Hall International, New

${ }^{39}$ Rollinson, D. (2002). Human Resources in Organisations. Pearson Education. , 567.

${ }^{40}$ Newstrom, J. W. \&K. Davis (2002). Organisational Behavior: Human Behavior at Work. , 91

${ }^{41}$ Huczynski, A., \& Buchanan, D. (2001). Organizational behaviour: An introductory text. Financial Times/Prentice Hall. , 624

${ }^{42}$ Kreitner, R., \& Kinicki, A. (2005). Perilaku organisasi. Jakarta: Salemba Empat. , 79

23

${ }^{43}$ Hodge, B. J. (1996). Organization theory: A strategic approach. Pearson College Division. ,

${ }^{44}$ Hofstede, G. (1986). Cultural differences in teaching and learning. International Journal of intercultural relations, 10(3), 301-320. 
Sementara Greenberg \& Baron $^{45}$ menyatakan bahwa terdapat tiga hal yang menciptakan budaya organisasi, yaitu; pertama, pendiri perusahaan (company founder). Kedua, pengalaman dengan lingkungan (experience with the environtment). Ketiga, berhubungan dengan orang lain (contact with others). Menurut Kreitner \& Angelo dalam hal menanamkan budaya organisasi diperlukan proses belajar yang meliputi beberapa hal berikut: 1) visi, misi, nilai dan meterial organisasi, 2) desain secara ruangan fisik, lingkungan kerja dan bangunan, 3) slogan, bahasa, akronim dan perkataan, 4) pembentukan peranan, program pelatihan, 5) pengajaran dan peatihan oleh manajer, 6) reward dan punishment, simbol status, dan kriteria promosi. 7) cerita, legendan dan mitos mengenai suatu peristiwa orang-orang penting. 8) aktivitas, proses atau hasil organisasi. 9) reaksi pimpinan terhadap insiden yang kritis pada organisais. 10) sistem dan prosedur organisasi. 11) orientasi organisasi dan kriteria gabungan yang digunakan untuk rekruitmen, seleksi, pengembangan, promosi, pemberhentian dan pengunduran diri karyawan. ${ }^{46}$

Schein melihat karakteristik budaya organisasi dari 3 (tiga) variable dimensi budaya organisasi, yaitu dimensi adaptasi eksternal (external adaptation tasks), dimensi integrasi internal (internal intergration tasks) dan dimensi asumsiasumsi dasar (basic underlying assumtions). ${ }^{47}$

Menurut Turner, karakteristik utama budaya organisasi yaitu: 1) identitas anggota organisasi, yaitu bagaimana pegawai mengidentifikasi diri dengan organisasi secara keseluruhan, 2) penekanan kelompok, yaitu bagaimana pekerjaan diorganisasikan sebagai suatu kelompok bukan individu. 3) fokus pada pegawai. 4) integrasi unit kerja, 5) mekanisme kontrol, yaitu bagaimana kebijakan, peraturan dan pengaruh langsung digunakan untuk mengendalikan perilaku pegawai, 6) toleransi resiko, yaitu bagaimana pegawai didorong untuk bersikap agresif, inovatif, dan mampu menghadapi resiko. ${ }^{48}$

Kreitner \& Angelo, menyatakan bahwa tiga karakteristik budaya organisasi yaitu: 1) budaya organisasi diberikan kepada karyawan baru melalui proses sosialisasi, 2) budaya organisasi mempengaruhi perilaku karyawan di

${ }^{45}$ Greenberg, J., \& Baron, R. A., 2003,“Behavior in Organizations, 8th Edition”. New Jersey: Pearson Education. , 52

${ }^{46}$ Kreitner, R. \& Angelo, K. 2005. Organizational Behavior. New Jersey: Mc Graw Hill Companies, Inc. , 39

${ }^{47}$ Schein, Edgar H. "How can organizations learn faster?: the problem of entering the Green Room." (1992). , 16. Retrieved from https://dspace.mit.edu/bitstream/handle/1721.1/2399/SWP-3409-45882883.pdf

${ }_{48}$ Turner, M. (1996). The literary mind: The origins of thought and language. Oxford University Press. , 241 
tempat kerja, 3) budaya organisasi berlaku pada dua tingkat yang berbeda, yaitu: pandangan ke luar dan kemampuan untuk bertahan terhadap perubahan). ${ }^{49}$

Sementara Jansen \& Luthans menyebutkan beberapa karakteristik penting budaya organisasi, yaitu: 1) aturan perilaku yang diamati, yaitu bahasa, istilah dan tirual umum yang digunakan oleh anggota organisasi dalam berinteraksi satu sama lain. 2) norma atau standar perilaku organisasi, 3) nili-nilai yang dominan atau yang utama, 4) filosofi, yang berisi beberapa kebijakan yang membentuk keperayaan organisasi mengenai bagaiamana karyawan atau pelanggan dilayani. 5) aturan, yaitu beberapa pedoman yang berkaitan dengan target pencapaian perusahaan. 6) iklim organisasi, merupakan keseluruhan perasaan yang disampaikan dengan pengaturan fisik, cara berinteraksi, dan cara anggota organisasi dengan pelanggan dan individu di luar organisasi. ${ }^{50}$

Adapun fungsi budaya organisasi menurut Robbins (1996: 294) adalah untuk: 1) menjadi penetap batas, 2) mengantarkan suatu perasaan identitas bagi anggota organisasi, 3) memudahkan timbulnya komitmen lebih luas dibanding kepentingan individu, 4) meningkatkan stabilitas sistem sosial dan perekat sosial yang membantu mempersatukan organisasi, 5) sebagai mekanisme kontrol dan menjadi panduan rasional yang membimbing dan membentuk sikap serta perilaku karyawan.

Menurut Kreitner \& Angelo budaya organisasi memiliki empat fungsi, yaitu: 1) sebagai identitas organisasi kepada karyawannya, 2) memudahkan terciptanya komitmen kolektif, 3) mempromosikan stabilitas sistem sosial, 4) membentuk perilaku membantu pimpinan dan merasakan keberadaanya. ${ }^{51}$ Sedangkan menurut Ndhara fungsi budaya organisasi adalah: 1) sebagai identitas dan citra suatu masyarakat atau kelompok, 2) sebagai pengikat suatu masyarakat atau kelompok, 3) sebagai inspirasi dan kebanggan, 4) sebagai kekuatan penggerak, melalui belajar sehingga budaya menjadi dinamis, 5) untuk membentuk nilai tambah (value added), 6) sebagai pola perilaku, 7) sebagai warisan (legacy), 8) sebagai pengganti dari formalisasi organisasi (subtitusi), 9) sebagai mekanisme adaptasi terhadap perubahan, 10) sebagai proses yang menjadikan bangsa kongruen dengan Negara sehingga terbentuk nation-state. ${ }^{52}$

\footnotetext{
${ }^{49}$ Kreitner, R. \& Angelo, K. 2005. Organizational Behavior. New Jersey: Mc Graw Hill Companies, Inc. , 39

${ }^{50}$ Jensen, S. M., \& Luthans, F. (2006), "Entrepreneurs as authentic leaders: impact on employees' attitudes", Leadership \& Organization Development Journal, 27(8), 646-666.

${ }^{51}$ Kreitner, R. \& Angelo, K. 2005. Organizational Behavior. New Jersey: Mc Graw Hill Companies, Inc. , 83-84

${ }^{52}$ Ndraha, T. (1997). Budaya organisasi. Jakarta: Rineka Cipta. , 47
} 
Selanjutnya terdapat tiga fase perkembangan sebuah organisasi, sebagaimana berikut: ${ }^{53}$ pertama, fase awal organisasi. Pada fase ini budaya organisasi menjadi pembeda antara lingkungan maupun kelompok atau organisasi lainnya. Kedua, fase pertengahan. Pada fase ini budaya organisasi berfungsi sebagai pemersatu (integrator) sebab pada fase ini muncul sub-sub budaya baru sebagai penyelamat krisis identitas dan membuka kesempatan untuk mengarahkan perubahan budaya organisasi. Ketiga, fase kematangan (dewasa). Fungsi budaya organisasi menjadi sebagai penghampat dalam berinovasi disebabkan kebesaran masa lalu, dan menjadi sumber nilai untuk berpuas diri.

\section{Amanah dalam al-Qur'an dan Relevansinya dengan Pengembangan Budaya Organisasi}

Didalam al-Qur'an setidaknya amanah disebutkan dalam lima (5) ayat, yaitu: (QS. An-Nisa[4]: 58), (QS. Al-Mu'minun[23]: 8), (QS. Al-Ma'arij[70]: 32), (QS. Al-Ahzab[33]: 72), (QS. Al-Anfal[8]: 27). Agar konsep amanah tersebut relevan dengan kondisi dewasa ini, beberapa makna dari ayat diatas setidaknya dapat dikategorikan kepada beberapa konsep sebagai berikut ini:

\section{Amanah Sebagai Konsep Keimanan}

Ibnu Mandzur menyatakan bahwa iman berkaitan erat, atau menjadi sinonim, dari kata iman, aman, tsiqah, sidiq, bafid» dan 'alim. ${ }^{54}$ Dengan demikian, amanah seseorang menujukkan keimanan atau amanah cerminan keimanan seseorang. Sebab amanah dapat dilihat, sebaliknya iman tidak terlihat. Sebagaimana Rasulullah Saw bersabda, 'al-imanu ba buna (sembari menunjuk ke dada). Sabda yang lain dinyatakan 'la imana liman la amanata lahu'(HR. Ahmad dan Ibnu Hibban)-tiada iman bagi mereka yang tidak menunaikan amanah mereka. Misalnya; seseorang yang berzina, maka imannya tidak ada ketika ia berzina, sebab ia mengingkari amanah yang terlah diberikan oleh Allah kepadanya. Akibat amanah tidak ditunaikan dan dijaga, maka tiada iman baginya.

Selanjutnya, menurut az-Zamakhsyari amanah adalah penuh atau lengkap (tamam) sedangkan antonim-nya adalah khiyanat yaitu kurang. ${ }^{55}$ Sifat ingkar atau khianat merupakan ciri seorang yang munafik sebab Islam menginginkan kesatuan dalam hati, lisan dan perbuatan, itulah iman (at-tashdiq bi al-qalbi, wa al-iqraru bi al-lisan wa al-amal bi al-jawarib an al-arkan).Dalam menjelaskan amanah ini, ketika menafsirka (QS. An-Nisa[4]: 58), Ibnu Katsir

\footnotetext{
53 Schein, Edgar H. "How can organizations learn faster?: the problem of entering the Green Room." (1992). ～ $16 . \quad$ Retrieved from https://dspace.mit.edu/bitstream/handle/1721.1/2399/SWP-3409-45882883.pdf

${ }^{54}$ Ibn Mandzur, Lisan al-'Arab, Juz.I, (Qahirah: Darul Ma’arif, 1998), , 140-144

55 Imam az-Zamakhsyari, Tafsir al-Kasysyaf, Juz. 2, Cet. I, (Riyadh: Maktabah 'Abikan, 1998), , 572-573
} 
menjelaskan bahwa orang mukmin jika dipercayakan kepadanya suatu urusan maka ia tidak berkhianat, tetapi menunaikan kepada ahlinya. Dan jika berjanji atau bertransaksi mereka akan memenuhinya, bukan seperti orang munafik. ${ }^{56}$ Sebagaimana sabda Rasulullah Saw,

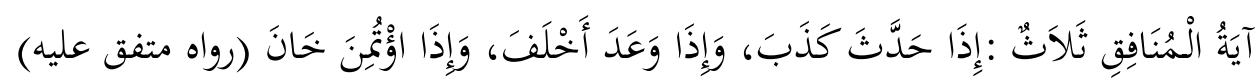

"Ciri-ciri orang munafik itu ada tiga: apabila berkata, berbohong. apabila berjanji memungkiri, dan apabila di percaya mengkbianati” (HR. Muttafaqun 'Alaib).

Iman merupakan hal yang abstrak, immateril, sebab letaknya dihati. Namun Allah Swt memberikan kita cara agar mengetahui apa yang ada dalam hati itu. Yaitu dengan mengetahui, apakah seseorang tersebut telah menjalankan amanat (plural; amanah) dengan baik atau tidak. Baik amanah kepada Allah Swt, manusia ataupun diri sendiri. Seseorang yang beriman, ketika berbuat maksiat maka akan berkurang, atau bahkan tidak ada iman baginya. Sebaliknya, ketaatan akan menjadikan iman bertambah dan sempurna. Amanah manusia adalah dengan menjalankan perintah Allah dan meninggalkan segala larangannya, mengikuti sunnah-sunnah Rasulullah dan khalifah setelahnya.

Adil dan amanah merupakan kunci nyata untuk melihat keimanan dan ketakwaan seseorang yang tidak nampak, hal ini dinyatakan dalam al-Qur'an (QS. Al-Ma'idah[5]: 8) dan (QS. An-Nisa'[4]: 58). Abi Hayyan al-Andalusi menyatakan, bahwa amanah merupakan perilaku yang dahulu harus dimiliki oleh seseorang, selanjutnya dengan amanah yang dimiliki digunakan untuk menasehati orang lain untuk berbuat amanah, hingga pada akhirnya berbuat adil jika mengambil keputusan. Senada dengan Abi Hayyan, Ibnu Katsir juga menyatakan bahwa amanah merupakan syarat untuk berbuat adil. Dalam menafsirkan (QS. Al-Baqarah[2]: 282), beliau menyatakan bahwa dalam transaksi (butang-piutang atau tidak cash) mencatat transaksi bagi si piutang merupakan bentuk amanah yang harus dilakukan, selain itu menyaksikan apa yang dicatat merupakan keharusan bagi si penghutang. Dengan amanah yang telah dilakukan tersebut, maka adil akan datang setalahnya. Yaitu kesesuaian antara apa yang ditransaksikan (butang-piutang) dengan apa yang dicatat dan disaksikan oleh kedua belah pihak. ${ }^{57}$

Menurut Ibnu Juraij, barang siang yang berpituang hendaknya menulis, dan yang berhutang menyaksikan. sedangkan menurut Qatadah, diceritkan kepada kami bahwa Aba Sulayman al-Mar’asyiy merupakan penjaga Ka’bah,

\footnotetext{
${ }^{56}$ Ibnu Katsir, Tafsir al-Qur'an al-'Adzim, Juz.X, Cet.I, (Giza: Mu’assasah Qurtubah li atThab'ah, an-Nasyr wa at-Tauzi', 2000), , 109-110

${ }^{57}$ Ibid, Ibnu Katsir, Tafsir al-Qur'an al-'Adzim, Juz.II, , 506.
} 
disebutkan pada suatu hari kepada kawannya: "apakah kamu tabu seseorang yang dizalimi berdoa kepada tubannya dan tiada jawaban baginya?". mereka berkata: "lalu bagaimana yang seperti itu?", lalu dia berkata "Seseorang yang malakukan transaksi jual beli dengan seseorang (butang pituang), lalu tidak disaksikan dan tidak pula ditulis, dan ketika uangnya bilang (tidak dibayar) dan yang berbutang tidak mengakui atau menghilang, lalu dia berdoa dan tidak ada jawaban baginya karena ia telah mengingkari perintah Tubannya”. Dan menurut Abu Sa'id wa as-Sya'biy, Rabi' bin Anas, Hasan, Ibnu Jutraij, Ibnu Zayd dan lainnya: ketentuan tersebut (mencatat dan menyaksikan) merupakan sebuah kewajiban, kemudian dihapus oleh Firman Allah $\mathrm{Fa}$ Inn Amana ba'dukum ba'dan falyu'addi alladzi u'tumina amanatabu'. dan dalil atas ini juga hadist yang diceritakan tentang syariat yang dilakukan oleh generasi sebelum kita, tanpa memungkiri urgensi pencatatan dan persaksian dalam jual beli, khususnya yang tidak tunai.

Hal senada juga dinyatakan oleh At-Thabari, ketika menafsirkan QS. AnNisa[4]: 58. Dinyatakan bahwa ayat ini diturunkan berkaitan dengan riba. Barang siapa yang mengalami kesulitan hendaknya dilonggarkan waktu pembayarannya. Sebagaimana dalam hadist Rasulullah Saw. dari Ya'qub diceritakan kepadaku oleh Ya'qub, dari Hasyim, dikabarkan oleh Mughirah, dari as-Sya'bi Sesungguhnya Ar-rabi' bin Khatsim memiliki hak (piutang) atas seseorang, kemudian ia mendatang rumah si penghutang pada pintu rumahnya sembari berkata, "Hai fulan, jikka kamu dalam keadaan mudah tunaikanlab amanahmu, jika dalam keadaan kesulitan maka bagimu kelonggaran waktu". Pada kasus tentang riba, dilihat kondisi yang berhutang, apakah ia dalam kesulitan atau tidak, bukan melihat kepada aspek amanah, akan tetapi harus diberikan kepada ahlinya. ${ }^{58}$ Sebagian lainnya, menyatakan bahwa ayat ini berlaku umum bagi mereka yang mengalami kondisi kesulitan, dan diberikan atas mereka hak atas kesulitan tersebut. Dari perspektif manupun selama berlandaksan kebenaran, dari hutangpiutang, ataupun riba. ${ }^{59}$ Dengan demikian, menangguhkan pembayaran hutang bagi si piutang merupakan bentuk amanah, yaitu menunaikan amanah kepada ahlinya (orang kesusahan).

\section{Amanah Sebagai Parameter Pemilihan Partner Kerja}

Nabi Musa dan Nabi Yusuf bekerja untuk Nabi Syu'aib menggembala domba. Sedangkan Nabi Yusuf menjadi menteri Keuangan Negara di Mesir pada masa Al-Aziz. Jika Nabi Musa menggunakan kekuatan fisik dan amanah dalam melaksanakan perkerjaannya. Nabi Yusuf menggunakan ilmu dan amanah sebagai penunjang untuk melaksakan tugasnya sebagai menteri keuangan. Ilmunya dapat menyelamatkan negeri Mesir dari paceklik makanan di musim

\footnotetext{
t.t.), , 30-31

58 Ibn Jarir at-Thabari, Tafsir At-Thabari, Juz.VI, (Qahirah: Maktabah Ibn Taymiyah,

${ }^{59}$ Ibid, Ibn Jarir at-Thabari, Tafsir At-Thabari, , 33
} 
kemarau. ${ }^{60}$ Fakta sejarah diatas menunjukkan bahwa amanah memiliki peran yang signifikan dalam memilih seseorang untuk bekerja, dalam bahasa modern disebut recruitment pegawai. Disisi lain, adalah adanya kekuatan yang dimiliki (alquwah) baik itu fisik maupun intelektual atau pengetahuan. Mungkin inilah rahasia mengapa dalam al-Qur'an Allah Swt tidak pernah menyuruh hambanya untuk mencari uang atau harta, namun yang diperintahkan ialah mencari karunia atau keutamaan yang diberikan oleah Allah Swt (ibtigha'i fadblillah). Keutamaan tersebut berupa materi ataupun pengetahuan, karena dengan dua hal itulah manusia diutamakan dengan sebagian yang lain. Perintah untuk memilih orang yang berilmu merupakan perintah Allah Swt dalam al-Qur'an, (QS. An-Nahl[16]: 43)

Dengan mendapatakan pengetahuan dan akhirnya akan berlaku benar dalam menjalankan segenap kewajiban dalam suatu perkara. Sebab jika tidak, maka akan mengakibatkan kehancuran sebagaimana sabda Rasulullah Saw, "Iika amanat telah disia-siakan, tunggu saja kehancuran terjadi." Seseorang sahabat bertanya; "bagaimana maksud amanat disia-siakan?", beliau menjawab, "Iika suatu urusan diserabkan bukan kepada ablinya, maka tunggulah saat kehancuran itu.” (HR. Bukhari)

Begitu pula disebutkan bahwa jika seorang pemimpin mengangkat seseorang untuk sesuatu, sedangkan terdapat seseorang yang lebih kompeten dan patut untuk memangku jabatan tersebut, maka sesungguhnya ialah mengkhianati Allah dan Rasulnya. Yang demikian, amanah merupakan sesuatu yang sangat penting didalam recruitment pegawai atau rekan kerja, dalam alQur'an Allah berfirman, dalam (QS. Shad[38]: 24), Daud berkata: "Sesunggubnya Dia telah berbuat zalim kepadamu dengan meminta kambingmu itu untuk ditambabkan kepada kambingnya. Dan Sesunggubnya kebanyakan dari orang-orang yang berserikat itu sebahagian mereka berbuat zalim kepada sebahagian yang lain, kecuali orang-orang yang beriman dan mengerjakan amal yang saleb; dan Amat sedikitlah mereka ini". Dan Daud mengetahui bahwa Kami mengujinya; Maka ia meminta ampun kepada Tuhannya lalu menyungkur sujud dan bertaubat.

Senada dengan ayat diatas, Rasulullah Saw bersabda,

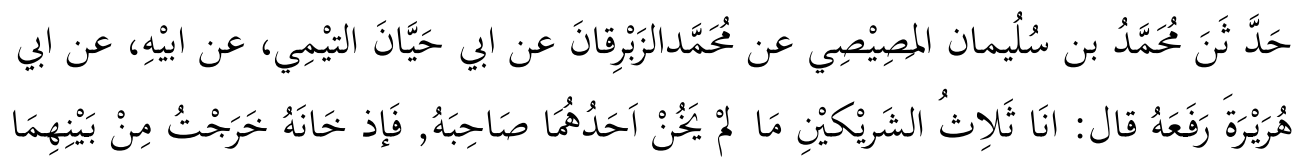

Telah bercerita kepada kami Muhammad bin Sulaiman Al- Mashishi dari Mubammad AlZabriqan dari Abi Hayyana Al-Taimi dari ayahnya dari Abi Hurairab telah berkata

${ }^{60}$ Ahmad Djalaluddin, Manajemen Qur'ani, Cet. II, (Malang: UIN Maliki Press, 2014), , 
Rasulullab: "Aku adalab yang ke tiga dari dua orang yang bersekutu selama salah satu diantara keduanya tidak berkhianat terbadap lainnya dan apabila mereka berkbianat aku keluar dari mereka" (HR. Abu Daud)

Jika dalam suatu persyarikatan atau pekerjaan baik itu dalam usaha maupun pendidikan, maka Allah akan berperan serta didalamnya dan Allah akan memberikan berkah. Disamping itu, terdapat faktor yang lainya yaitu: tidak nepotisme, dan kharisma seseorang, atau tokoh masyarakat atau lingkungan setempat.Dua hal diatas jika ditelisik lebih dalam, secara implisit akan mengacu kepada amanah yang dimiliki seseorang. Sebab dalam lisanu al-'Arab Ibnu Mandzur menyandingkan antara kata amanah, iman, tsiqah, 'alim, hafidz dan shadiq.

Seseorang dikatakan mukmin jika perilakunya dan keputusannya menenangkan dan menentramkan orang lain. Jika yang dilakukan adalah nepotisme atau mengangkat seseorang yang tidak kompeten dalam bidang yang ditugaskan, dan pada akhirnya akan mengakibatkan kekacauan dan perpecahan dalam masyarakat (pro-kontra dalam setiap kebijakan), maka seseorang yang mengangkat dan yang diangkat dapat disebut tidak menunaikan amanah. Sebagaimana disebutkan oleh Az-Zamakhsyari, bahwa amanah adalah sempurna atau utuh, dan khianat adalah kurang. Jika ia mengangkat seseorang yang tidak kompenten (tidak abli) disebabkan karena nepotisme dan memilih seseorang yang dijadika tokoh (panutan) maka belum sempurna amanahnya sebagai pemimpin.

\section{Amanah Sebagai Nilai Budaya Organisasi}

Amanah juga dapat dijadikan sebagai fondasi dari budaya organisasi, setidaknya terdiri dari beberapa bagian, yaitu: Saling percaya (tsiqab), objektif dalam bertindak (tajarrud) dan loyal kepada pemimpin dan peraturan (ta'at). ${ }^{61}$

\section{Saling percaya (tsiqah) menimbulkan kepercayaan anggota organisasi}

Tsiqah adalah tentramnya seseorang pada suatu pikiran, organisasi, orang atau pimpinan. Ketentraman ini kemudian berbuah penerimaan terhadap pikiran, organisasi, seseorang dan pimpinan itu. Dalam risalah ta'lim, tsiqah didefinisikan dengan tentramnya anggota kepada pimpinannya dalam hal kemampuan dan keikhlasannya. Ketentraman yang mendalam menghasilkan cinta, penghargaan, penghormataan, ketaatan. ${ }^{62}$

Tsiqahnya seseorang terhadap pikiran, organisasi atau pimpinan akan muncul ketika ia melihat adanya keatuan antara pikiran dengan realitas, program dengan penerapan, dan antara ucapan dengan perilaku seseorang, maupun pimpinan pada sebuah organisasi. Pepatah arab menyatakan, lisanu al-hal afsah

\footnotetext{
${ }^{61}$ Ibid, Ahmad Djalaluddin, Manajemen Qur'ani.., , 117, 191, 201
}

${ }^{62}$ Majalah al-Wa'i dalam Ahmad Djalaluddin, 117 
min lisanul maqal -efektivitas perbuatan (dalam menciptakan perubahan) lebih manjur ketimbang perkataan.

Dan tsiqah akan sirna jika pikiran bertolak belakang dengan realitasnya, organisasi tidak mampu menerjemahkan cita-citanya, atau tidak ada kesesuaian antara tindakan dan ucapan pimpinan. Tsiqah dalam diri akan menguat bila kesesuaian itu ia saksikan secara berkesinambungan. Tsiqah adalah cabang ketaatan dan komitmen, atau dapat pula menjadi fondasi keduanya. Maka tidak ada kedisiplinan tanpa ketaatan, taka da ketaatan tanpa ketsiqahan. Penguatan tsiqah pada diri berimplikasi pada kepercayaan diri pada komunitas dan organisasi. Jika percaya diri hilang, maka organisasi akan hancur. Tsiqah pada pimpinan timbul dalam bentuk ketentraman dan keyakinan dalam hati para anggota bahwa pimpinan itu akan mempu membawa mereka pada kebaikan, merealisasikan cita-cita dan tujuan, serta mewujudkan kemaslahatan bersama. ${ }^{63}$

Apabila ketaatan dalam sebuah organisasi dibangun dengan sekadar mengerjakan tugas untuk menggugurkan kewajiban dengan mengesampingkan pondasi tsiqah, maka secara perlahan akan menurunkan kualitas kinerja. Yang diharapakan adalah peningkatan kinerja, dengan upaya serius menjaga kepercayaan; baik kepada fikrah (ide atau konsep) serta kepada personal (pemimpin).

Kepercayaan berasal dari faktor internal dan eksternal; internal meliputi fikrah, ide konsep yang teguh yang diyakini. Fikrah mendatangkan keteguhan jiwa, keyakinan dan kepercayaan terhadap apa yang ia perjuangkan. Internal: adalah individu para pemimpin itu sendiri. Pemimpin dalam sebuah organisasi adalah tempat panutan, dan objek kepercayaan. Tinggi rendah kepercayaan kelompok bergantung kepada karakter dan prestasi pemipin itu sendiri. ${ }^{64}$

Hubungan ideal antara pemimpin dengan anggota harus disertai dengan kepercayaan timbal balik anta kedua belah pihak. Dengan adanya kepercayaan tersebut, maka kepercayaan dan integritas sebuah organisasi akan meningkat. Sebaliknya, jika terjadi sebuah pengkhianatan dan penempatan seseorang yang bukan ahlinya pada suatu pos pekerjaan, maka akan menurunkan kepercayaan inetrnal dan eksternal organisasi.

Selain percaya kepada anggota, percaya kepada diri sendiri juga penting guna mengambil keputusan penting dalam suatu organisasi, jika kepercayaan diri hilang, maka akan gamang dalam memutuskan suatu keputusan yang pada akhirnya akan membahayakan organisasi. Percaya diri juga dapat membantu

${ }^{63}$ Ibid, Ahmad Djalaluddin, Manajemen Qur'ani...., , 178-179
${ }^{64}$ Ibid, Ahmad Djalaluddin, Manajemen Qur'ani...., , 180 
untuk mengambangkan diri. Namun, percaya diri saja tidak cukup dan memerlukan sandaran yang kokoh, sebab diri manusia adalah lemah dan mudah goyah. Makan diperlukan sandaran yang kokoh yaitu Allah Swt.

Kehidupan organisasi yang dibangun atas landasan tsiqah timbal balik antara pemimpin dan yang dipimpin akan mewujudkan beberapa hal berikut: ${ }^{65}$

1) Membangkitkan kemampuan, mempertajam obsesi tinggi, dan memotivasi mereka untuk terus menerus berinovasi yang membuat mereka bangga dengan pompinanya serta merasa bertanggungjawab

2) Kepercayaan mereka yang utuh terhadap pemimpinan karena ia selalu memberlakukan mereka lebih dari hak-hak yang seharusnya mereka terima, juga mengeksplorasi kelebihan-kelebihan mereka yang tersembunyi dan mengembangkanya, tanpa harus selalu melihat kesalahan mereka

3) Memanfaatkan seluruh kemampuan mereka untuk berkarya, karena mereka merasakan bahwa pemimpin mereka penuh perhatian dan terus memotivasi mereka.

\section{Bersikap objektif (tajartud): menciptakan dedikasi pada organisasi}

Tajarrud memiliki arti totalitas. Dimana seseorang tidak mencampuri sesuatu dengan yang lain. Pribadi yang memiliki sifat tajarrud ialah mereka yang tekun dalam pekerjaannya, sepenuh hati dan sepenuh jiwa. Kedua, berarti membersihkan dan melepaskan diri dari keterikatan dengan sesuatu yang membebani dan menghambat dalam pengambilan keputusan maupun sikap. Dalam konteks ini, seseorang yang bertajarrud melepaskan diri dari perpsepsi, prasangka, dan paradigma yang cenderung negatif dan menggantinya dengan kemurnian fikiran, berbaik sangka dan penuh aura positif dalam diri. Ketiga, berarti memutuskan suatu ketetapan (menghukumi) seseorang secara proporsional dan obyektif, dan adil tanpa dipengaruhi dengan pengalaman masa lalu, ataupun latar belakang kehidupannya. Tajarrud menjadikan seseorang tidak menjadi pendendam, justru memaafkan dan berbuat adil, dan tidak berbuat nepotisme kepada siapa saja yang telah berbuat baik kepadanya. ${ }^{66}$

Dalam suatu organisasi tajarrud tercakup dalam hal berikut: ${ }^{67}$

1) Tajarrud fikri. Yaitu ikatan yang melekat dalam diri individu-individu yang berada dalam suatu organisasi. Ada komitmen untuk menyatukan individu-individu yang ada didalam suatu organisasi

\footnotetext{
${ }^{65}$ Jamal Mahdi, dalam Ahmad Jalaluddin, Manajemen Qur'ani, ,188-189

${ }^{66}$ Ibid, Ahmad Djalaluddin, Manajemen Qur'ani...., , 191, 195, 198

${ }^{67}$ Ibid, Ahmad Djalaluddin, Manajemen Qur'ani...., , 199
} 
2) Tajarrud rubi atau totalitas menjaga kebersihan hati dari segala keinginan kotor dan ambisi yang menyimpang. Diperlukan keikhlasan dalam mengemban dan memperjuangkan visi dan misi organisasi

3) Berupaya memfungsikan diri sebagai bagian yang bermanfaat bagi komunitasnya. Menerima dan melaksanakan tugas secara optimal, dan tidak menyepelekan.

4) Menumbuhkan rasa tanggungjawab terhadap organisasi. Masing-masing anggota merasa dirinya bertanggung jawab dan berperan. Dengan demikian, jika terdapat kekurangan dalam suatu hal akan berusaha untuk memperbaikinya sehingga organisasi dapat mencapai visi misi yang telah dicanangkan.

\section{Loyalitas (taat): membangun soliditas organisasi}

Taat memiliki tempat yang penting dan strategis dalam kepemimpinan Islam. Ia adalah ikatan yang paling kuat antara seseorang pemimpin dangan anggotanya. Al-Qur'an mengharuskan kepada segenap Muslimin untuk menta'ati pemimpin-pemimpin mereka setelah taat kepada Allah dan Rasul-Nya (QS. AlAnfāl[8]: 27), "Hai orang-orang yang beriman, janganlab kamu mengkbianati Allah dan Rasul (Mubammad) dan (juga) janganlah kamu mengkhianati amanat-amanat yang dipercayakan kepadamu, sedang kamu mengetabui".

Beberapa prinsip yang terdapat dalam ketaatan kepada pemimpin meliputi: (1) hierarki ketaatan dimulai dari taat kepada Allah, Rasul-Nya dan pemimpin suatu golongan (ulil amri minkum). (2) ketaatan harus dalam hal yang bedimensi ibadah, bukan masksiat (la ta'ata fi al-ma'siyab). ${ }^{68}$ Begitu pula dalam kaitannya dengan kemudahan dalam agama tidak diperkenankan dalam hal yang bersifat maksiat sebagaimana disebutkan dalam prinsip fiqh, ar rukhsu la tunatu fil ma'ashi-keringanan (rukbsah) tidak diperuntukkan pada hal maksiat.

Taat merupakan kritikal point bagi soliditas suatu organisasi. Suatu organisasi tak akan berumur panjang bila yang dipimpin berjalan sendiri, enggan mendengar dan mentaati apa yang ditetapkan oleh pimpinan. Keadaan menjadi tak terkendali bila tidak ada kesepakatan bersama. Sebagaimana dinyatakan oleh khalifah 'Umar bin Khattab, 'la jama'ata illa bi al-imarah, wa la 'imarata ill bi attha'ah'-tiada kebersamaan tanpa kepemimpinan (organisasi), tiada kepemimpinan tanpa ketaatan. Ketaatan dalam kepemimpinan (organisasi) memiliki beberapa konsekuensi sebagai berikut: ${ }^{69}$

1) Taat dalam perkara yang disukai atau tidak disukai

${ }^{68}$ Ibid, Ahmad Djalaluddin, Manajemen Qur'ani...., , 205

${ }^{69}$ Ibid, Ahmad Djalaluddin, Manajemen Qur'ani...., , 206-209 
Terkadang arahan atau instruksi yang diberikan oleh pimpinan tidak sepenuhnya dapat diterima oleh para anggota. Oleh karena itu diperlukan ketaatan para anggota, selama itu masih dalam koridor kebenaran dan berjalan sesuai dengan garis yang dirumuskan sebuah organisasi.

2) Taat dengan respon cepat (sur'atul khatir) perintah atasan.

Diantara sebab kejatuhan ummat terdahulu adalah banyaknya pertanyaan yang dajukan dalam setiap perintah. Sebab sebenarnya perintah adalah untuk dikerjakan bukan dipertanyakan. Namun ini bukan berarti bertanya terhadap perintah dilarang, hanya saja pertanyaan yang berlebihan selain mengakibatkan hilangnya semangat kerja, juga akan menyusahkan diri sendiri.

Hal ini terjadi kepada kaum yahudi ketika diperintahkan oleh Nabi Musa untuk menyembelih sapi, kemudian kaum Yahudi bertanya secara mendetail dan mendalam tentang sapi tersebut. Pada akhirnya, bukan mengerjakan perintah mereka malah ingkar terhadap perintah tersebut.

3) Ketaatan perlu keikhlasan

Ketaatan itu ibarat hidayah, yang perolehannya diberikan oleh Allah Swt kepada siapa saja yang dikehendaki. Meskipun manusia memiliki peran untuk mencari dan mempelajarinya. Ada atau tidaknya pemimpin, tidak mempengaruhi ketaatan dan loyalitasnya pada tugas yang menjadi tanggung jawabnya. Pentingnya keikhlasan dalam setiap amal perbuatan disebutkan dalam firman Allah, 'wa ma umiru illa liya'budu Allab mukblisina labu ad-din -dan tidak diperintahkan untuk beribadah kepada Allah kecuali dengan hati yang ikhlas. Begitu pula sabda Rasulullah Saw, 'innama al-A'malu bi an-niyat wa innama likekulli imri'in ma nawa' -segala sesuatu (perbuatan) bergantung pada niatnya, dan setiap perbuatan seseorang akan dinilai bergantung pada yang diniatkannya (HR. Bukhari dan Muslim)

\section{Amanah sebagai parameter kesuksesan}

Berdasarkan firman Allah dalam (QS. al-Mu'minun [33]: 1-8), Sesungguhnya beruntunglah orang-orang yang beriman, (yaitu) orang-orang yang khusyu' dalam sembahyangnya, dan orang-orang yang menjauhkan diri dari (perbuatan dan perkataan) yang tiada berguna, dan orang-orang yang menunaikan zakat, dan orang-orang yang menjaga kemaluannya, kecuali terhadap isteri-isteri mereka atau budak yang mereka miliki. Maka Sesungguhnya mereka dalam hal ini tiada tercela. Barangsiapa mencari yang di balik itu, Maka mereka Itulah orang-orang yang melampaui batas. dan orang-orang yang memelihara amanat-amanat (yang dipikulnya) dan janjinya, dan orang-orang yang memelihara sembahyangnya.

Seseorang mukmin akan beruntung apabila memiliki perilaku sebagaimana berikut; khusyu' shalatnya, menjauhkan diri dari hal yang tidak 
bermanfaat, menunaikan zakat, menjaga kemaluannya, memelihara amanat serta memelihara shalatnya. Menurut sebagian ulama', amanah merupakan faktor penting (al-mashdar) dari kunci keberuntungan seorang Mukmin, selain beberapa faktor yang telah disebutkan. Sebagian lain menyatakan bahwa amanah bukanlah faktor penting dari keberuntung seorang mukmin, melainkan beberapa faktor diatas inilah yang secara bersamaan berperan menjadikan kesuksesan seorang mukmin. ${ }^{70}$

Ayat diatas merupakan perincian dari firman Allah dalam al-Qur'an (QS. Al-Hujurat[49]: 13), "Hai manusia, Sesungguhnya Kami menciptakan kamu dari seorang laki-laki dan seorang perempuan dan menjadikan kamu berbangsa bangsa dan bersuku-suku supaya kamu saling kenal-mengenal. Sesungguhnya orang yang paling mulia diantara kamu disisi Allah ialah orang yang paling taqwa diantara kamu. Sesungguhnya Allah Maha mengetahui lagi Maha Mengenal."

Berdasarkan ayat diatas dinyatakan bahwa kesuksesan seseorang bukan hanya diukur berdasarkan faktor materi semata, namun faktor immateri juga menjadi faktor penentu dari kesuksesan. Dalam kaitannya dengan amanah, kesuksesan seseorang dalam konteks amanah secara garis besar meliputi dua hal; ketenangan dan ketentraman bathin dan kecukupan materi, berupa; terpenuhinya sandang, pangan, dan papan (SPP), kejujuran dalam jual beli (bebas dari gharar - disebut dengan kullu bay'in mabrur), dan terpenuhinya kewajiban dan hak sesama manusia. (QS. Al-Quraisy[106]: 3-4), (QS. AlBaqarah[2]: 155).

\section{Kesimpulan}

Berdasarkan penjelasan diatas kesimpulan dari penelitian adalah bahwa makna dan klasifikasi amanah Qur'ani memiliki peran dalam memperkaya pengembangan budaya organisasi di era disrupsi. Hal ini disebabkan karena budaya organisasi merupakan nilai kebajikan yang disebraluskan dalam sebuah organisasi. Dengan demikian, jika nilai amanah yang memiliki arti kondisi tenang, komit terhadap titipan (wadìab) janji atau kewajiban (wafä), konsisten dan komitmen (tsabāt 'alal 'Abdi) dapat menjadi budaya organisasi yang disebarluaskan dalam sebuah organisasi, maka organisasi tersebut akan berjalan secara efektif dan efisien.

70 Abi Hayyan al-Andalusi, Tafsir al-Babrul Muhith, Juz.VI, Cet. I, (Beirut-Lebanon: Darul Kutub al-'Alamiyyah, 1993), , 367-368 
142 | AL QUDS : Jurnal Studi Alquran dan Hadis vol. 4, no 1, 2020

\section{Bibliografi}

'Arabi, Ibnu. (2003). Abkam Al-Qur'an. Edited by Muhammad 'Abdul Qadir 'Atha.' Juz 1. $2^{\text {nd }}$ ed. Beirut-Lebanon: Darul Kutub al-'Alamiyyah,

Abidin, Z. \& Khairudin, F. (2017). "Penafsiran Ayat-Ayat Amanah Dalam AlQur'an” Jurnal Syahadah, 5(2), 119-44.

Agung, I. M. \& Husni, D. (2016). "Pengukuran Konsep Amanah Dalam Pendekatan Kualitatif Dan Kuantitatif.” Jurnal Psikologi, 43(3) 194-206.

Agung, I. M. \& Herwanto, J. (2018). "Pedagang Yang Amanah: Studi Eksplorasi Dengan Pendekatan Psikologi Indigenous." PSYMPATHIC: Jurnal Ilmiah Psikologi, 4(1), 133-40.

Al-Andalusi, Abi Hayyan. (1993). Tafsir Al-Bahrul Mubith. Juz.IV. 1st ed. BeirutLebanon: Darul Kutub al-'Alamiyyah.

Al-Asfāhanī, Rāghib. (1991). Al-Mufradāt Fi Gharīb Al-Qur'ān. Edited by Muhammad Sayyid Kailānīy. Beirūt-Lebanon: Dār al-Ma'rifah.

Amrullah, Abdul Malik Karim. (1976). Tafsì Al-Az̧är. Ju\%: XVIII. 1st ed. Surabaya: H Abdul Karim.

Ar-Rāzi, Muhammad Fakhruddīn. (1981). Tafsìr Al-Kabìr Wa Mafätihu Al-Ghayb. Ju₹: X. 1st ed. Beirūt-Libanon: Dār Al-Fikr.

At-Thabarī, Abī Ja'fār. (2003). Tafsìr At-Thabarì. Edited by 'Abdullāh Ibn 'Abdullah al-Muhsin At-Turkīy. Juz.VII. 1st ed. Hijr li at-Tab'ah wa AnNasyr.

At-Thabari, Ibn Jarir. (1955). Tafsir At-Thabari. Ju₹.VI. Qahirah: Maktabah Ibn Taymiyah.

Az-Zamakhsyari, Imam. (1998). Tafsir Al-Kasysyaf. Jur. 2. 1st ed. Riyadh: Maktabah 'Abikan.

Az-Zuhaily, Wahbah. (1996). Tafsir Al-Wajiz 'Ala Hamisy Al-Qur'An. 22nd ed. Damaskus-Suriah: Darul Fikr.

Cherrington, D. J. (1989). The Management of Individual and Organizational Performance: Instructor's Manual for Organizational Behavior. Allyn and Bacon.

Dalimunthe, R. P. (2016). “Amanah Dalam Perspektif Hadist." Diroyab: Jurnal Ilmu Hadis, 1(1), 7-16.

Djalaluddin, A. (2014). Manajemen Qur'ani. ${ }^{\text {nd }}$ ed. Malang: UIN Maliki Press.

Hayyān, Muhammad ibn Yūsuf bin 'Al̄i ibn Yūsuf ibn. (1977). Al-Babr AlMubith. Beirut: Dâr al-Fikr. 
Greenberg, J., \& Baron, R. A., 2003, "Behavior in Organizations, 8th Edition”. New Jersey: Pearson Education.

Hafni, D. A. \& Harventy, G. (2013). "Membingkai Good Corporate Governance Amal Usaha Muhammadiyah Dalam Kerangka Amanah." Jurnal Akuntansi \& Investasi, 14(2), 85-95.

Hakim, R., Sawarjuwono, T., \& Djalaluddin, A. (2018). Proposing the value of Amanah as the foundation of Zakah organizational culture. OPCION, $1(2), 35-21$

Hasibuan, M. A. I., Anindhita, N., Maulida, N. H., \& Nashori, F. (2018). "Hubungan Antara Amanah Dan Dukungan Sosial Dengan Kesejahteraan Subjektif Mahasiswa Perantau." Psikohumaniora: Jurnal Penelitian Psikologi, 3(1), 101-116.

Hermanto, B., \& Rusdin. (2013). "Budaya Organisasi, Penciptaan Nilai, Dan Kinerja Organisasi." Jurnal Administrasi Bisnis, 9(2), 82-94.

Hodge, B. J. (1996). Organization theory: A strategic approach. Pearson College Division.

Hofstede, G. (1986). Cultural differences in teaching and learning. International Journal of intercultural relations, 10(3), 301-320.

Huczynski, A., \& Buchanan, D. (2001). Organizational behaviour: An introductory text. Financial Times/Prentice Hall.

Jensen, S. M., \& Luthans, F. (2006), "Entrepreneurs as authentic leaders: impact on employees' attitudes", Leadership \& Organization Development Journal, 27(8), 646-666.

Katsir, Ibnu. (2000). Tafsir Al-Qur'an Al-'Adrim. Ju\%. X. 1st ed. Giza: Mu'assasah Qurtubah li at-Thab'ah, an-Nasyr wa at-Tauzi'.

Katsīr, Imāduddīn Abī al-Fidā' Ibnu. (2001). Tafsìr Al-Qur'ān Al-'Adrìm. Edited by Musthafā as-Sayyid Muhammad. Juz XI. Qāhirah: Mu'assasah Qurtūbah.

Kreitner, R. \& Angelo, K. 2005. Organizational Behavior. New Jersey: Mc Graw Hill Companies, Inc.

Kusumawardani, L. (2010). "Budaya Organisasi Dalam Meningkatkan Kinerja Karyawan.” BISMA Jurnal Bisnis Dan Manajemen, 2(2), 159-66.

Ma'lūf, Lewis. (2000). Al-Munjid Fi Al-Lughah. 1st ed. Lebanon-Beirūt: Dār alMasyriq. 
144 | AL QUDS : Jurnal Studi Alquran dan Hadis vol. 4, no 1, 2020

Masdar, S., Asmorowati, S., \& Irianto, J. (2009). Manajemen Sumber Daya Manusia Berbasis Kompetensi Untuk Pelayanan Publik. Surabaya: Airlangga University Press.

Majeed, Y., Khalid, Z., \& Khan, M. A. (2011). The impact of Islamic leadership on organizational Objectives. Far East Journal of Marketing and Management, 1(5), 54-65.

Mandzur, Ibn. (1998). Lisan Al'Arab. Juz 1. Qahirah: Darul Ma'arif.

Ndraha, T. (1997). Budaya organisasi. Jakarta: Rineka Cipta.

Newstrom, J. W. \&K. Davis (2002). Organisational Behavior: Human Behavior at Work.

Robbins, SP (1998). Organizational Behavior, Prentice-Hall International, New Jersey.

Rollinson, D. (2002). Human Resources in Organisations. Pearson Education.

Salleh, M. J., \& Mohamad, N. (2012, November). Islamic principles of administration: implications on practices in organization. In Technology, Science, Social Sciences and Humanities International Conference, Langkawi, 14 \& 15 November 2012, Malaysia. (pp. 1-12)

Schein, Edgar H. "How can organizations learn faster?: the problem of entering the Green Room." (1992). Hal. 16. Retrieved from https://dspace.mit.edu/bitstream/handle/1721.1/2399/SWP-3409_45882883.pdf

Supriyanto, E. (2000) "Konsep Manajemen Amanah (Kajian Teoritik Terhadap Sistem Fillacial Perbankan Islam)." EL HARAKAH Jurnal Budaya Islam 2(1), 46-50.

Quthb, Sayyid. (2001). Tafsir Fi Zhiläli Al-Qur'ān. Edited by As'ad Yasin. Juz. II. $1^{\text {st }}$ ed. Jakarta: Gema Insani Press.

Turner, M. (1996). The literary mind: The origins of thought and language. Oxford University Press. 